\title{
Decadal-Scale Vegetation Dynamics of Kolkata and Its Surrounding Areas, India Using Fuzzy Classification Technique
}

\author{
Arun Mondal ${ }^{1}$, Anirban Mukhopadhyay ${ }^{2}$, Subhanil Guha ${ }^{3}$, Sananda Kundu ${ }^{1}$, \\ Sandip Mukherjee ${ }^{4} \&$ Rajarshi Dasgupta ${ }^{5}$ \\ ${ }^{1}$ Department of Water Resources Management and Development, Indian Institute of Technology, Roorkee, India \\ ${ }^{2}$ School of Oceanographic Studies, Jadavpur University, Kolkata, India \\ ${ }^{3}$ Department of Geography, Rammohan College, Kolkata, India \\ ${ }^{4}$ National Technical Research Organization, New Delhi, India \\ ${ }^{5}$ Department of Geography, Vidyasagar College, Kolkata, India
}

Correspondence: Anirban Mukhopadhyay, School of Oceanographic Studies, Jadavpur University, India. Tel: 91-983-143-2302. E-mail: anirban_iirs@yahoo.com

Received: June 5, 2012 Accepted: August 20, 2012 Online Published: September 1, 2012

doi:10.5539/enrr.v2n4p18 URL: http://dx.doi.org/10.5539/enrr.v2n4p18

\begin{abstract}
Vegetation is an important component of any ecosystem. In urban areas, presence of vegetation is essential for reducing the effects of environmental pollution and maintaining the ecological balance. In the wake of excessive growth of population, the urban vegetation with parkland, especially in developing countries, are diminishing rapidly to provide additional space to various other types of land use. However, such reductions can have serious future implications. Therefore, an assessment of the vegetation cover of urban areas is essential. In this paper, Landsat satellite imageries have been used to study the changes in the vegetation cover of Kolkata, the largest metropolis in eastern India, from 1973 to 2011. The entire area of Kolkata and its surroundings (up to a distance of $10 \mathrm{~km}$ ) has been divided into four quadrants according to the cardinal directions (northeast, southeast, southwest and northwest) and six concentric rings of $2 \mathrm{~km}$ radius each, and from these 24 sectors (four quadrants and six concentric circles), vegetated lands have been identified for analyzing the changes during the study period. There is a constant decrease of vegetation cover from 1973 till date. The outer periphery of the city is characterized by more urban vegetation as compared to the core of the city. Apart from this, the western sector is denser in terms of vegetation than the eastern one.
\end{abstract}

Keywords: vegetation cover change, landsat, remote sensing, fuzzy classification

\section{Introduction}

Urbanisation is occuring very rapidly in the whole world. Since 1990, the global urban population has approximately increased by 1.1 billion, most of which has occurred in the developing countries (Bremner et al., 2010). To accommodate rapidly growing population, the land use/land cover of urban areas is undergoing drastic change. The most notable of these is the reduction of vegetation cover. Besides directly changing the land use, increasing urban population also means rising level of emissions (Stern, 2007), which is affecting the micro-climate of the cities. Such micro-climates drive environmental changes at multiple scales (Grimm et al., 2008). One such process is the generation of Urban Heat Islands; the cities are always warmer than their surrounding areas (Oke, 1973). Vegetation helps to positively influence urban micro-climates, water and air quality. Besides, it has some societal value also; for e.g., research has shown that urban vegetation can reduce incidence of crimes (Kuo \& Sullivan, 2001). Besides, it can also have positive psychological effects on humans (Fuller, Irvine, Devine-Wright, Warren, \& Gaston, 2007). However, it is, in turn, affected by the stresses associated with urban areas, mainly pollution that can reduce species cover and richness (Emmanuel, 1997; Altobelli, Bressan, Feoli, Ganis, \& Martini, 2007; Williams et al., 2009). In fact, it has been found that while the positive effects of natural vegetation on urban environment is a long-term process, the adverse effects of the latter on the former occur on shorter time scales (Kowarik, 1990; Von Stülpnagel, Horbert, \& Sukopp, 1990). In view of these effects, during the $11^{\text {th }}$ Five Year Plan, the Government of India (2006) set a target of increasing the forest cover upto $33 \%$, especially in urban areas, but in most places, this law is not being followed. Therefore, 
it is important that assessments of vegetation cover of Indian cities be made from time to time and this paper endeavours to make a contribution in this respect.

Some studies have been made in the past to study the vegetation dynamics of cities in developing countries. Kwarteng and Chavez Jr. (1998) analyzed land cover changes brought about by an oil spill in Kuwait City in 1991. They found that the spill affected the urban vegetation, as a result of which it declined considerably. Mundia and Aniya (2006) studied the dynamics of land use/land cover over 24 years in Nairobi, Kenya using unsupervised classification technique. They found that forest cover declined by $77 \%$ during the study period, mainly due to expansion of built-up areas and agricultural lands, which in turn have impacts on the overall environmental quality of the city and its suburbs. Normalized Difference Vegetation Index (NDVI) analysis revealed that vegetation cover in a suburb of Beijing, China declined by $4 \%$ in a 26 year period mainly due to residential expansion (Liu, Wang, \& Zhao, 2009). Similar changes were found to have occurred in West African cities by urbanization and other developmental activities over a period of 50 years (Brinkmann, Schumacher, Dittrich, Kadaore, \& Buerkert, 2012). However, such studies are very few in India. The only study that the authors are aware of is by Nagendra, Nagendran, Pal and Pareeth (2012). They found that within the southern city of Bangalore, there were anomalous changes of vegetation cover. The core areas have their vegetation well protected, but towards the fringe areas, vegetation is undergoing rapid transformation due to urbanization.

Most of the above-mentioned studies have been carried out using traditional, pixel-based classification techniques. These techniques have their own limitations (Blaschke \& Strobl, 2001). Besides, in urban areas lots of mixed pixels are found which are difficult to classify with proper accuracy. Fuzzy classification is more flexible and gives control on the processes for assessment and therefore is extremely helpful for assessing vegetation of a region. Different types of vegetation with different intensities have been found in the given study area. In case of any hard classification (supervised or unsupervised), where there is rigid class identification, some less intensified or scattered vegetated areas may be missed out, giving larger errors in case of classification. But in case of soft classification like fuzzy, it is possible to assign the point on the basis of its degree of belonging to a particular cluster measured from the centroid point of the cluster. Thus it avoids the problem of any hard classification. Many studies, with application of fuzzy c-mean on vegetation have been done. Lucieer (2006) and Zhang and Foody (2001) have applied fuzzy C-Means classifier for estimation of the vegetation unit abundance per pixel. Arnot and Fisher (2007) have also used fuzzy algorithm for representing vegetation with ecotones as dominant structure in the landscape. Other researchers who have extensively used fuzzy for vegetation interpretation are Foody (1992), Moraczewski (1993), Schmidtlein and Sassin (2004), Lees (2006) and Lucieer (2006). According to Foody (1992), Lucieer (2006), Lu and Weng (2007) and Oldeland et al. (2010) fuzzy classification is considered as an important technique for mapping natural vegetation as it is possible to overlap many hard classes by soft technique.This paper uses a Fuzzy logic approach to determine the changes in vegetation of Kolkata over a period of 38 years (1973-2011).

\section{Study Area}

The area selected for the present work is the city of Kolkata and its surroundings. Kolkata ( $22^{\circ} 34^{\prime} \mathrm{N}$ and $88^{\circ} 24^{\prime}$ E) is the capital of the state of West Bengal and the largest metropolitan city in eastern India. The city itself is a district, having an area of $190 \mathrm{sq}$. $\mathrm{km}$. It has about 4.5 million people (Census of India, 2011a). The Kolkata Metropolitan Area (KMA) is, however, much larger. It occupies an area of $1886.67 \mathrm{sq} . \mathrm{km}$, and in 2011 had about 14.11 million people (Kolkata Metropolitan Development Authority [KMDA], 2010; Census of India, 2011b). Geographically, the KMA consists of Kolkata city and parts of the districts of North 24 Parganas, South 24 Paraganas, Howrah, Hooghly and Nadia. As a result of continual expansion, the land use/land cover of the city and its surrounding areas is undergoing rapid transformation. The maximum brunt of such transformations is being borne by the vegetation. Therefore, this study aims to map the current status of vegetation in Kolkata and its surroundings. To that end, a circular buffer zone, having a radius of $10 \mathrm{~km}$, has been selected (Figure 1). The study area extends from $22^{\circ} 21^{\prime} \mathrm{N}$ to $22^{\circ} 43^{\prime} \mathrm{N}$ latitudes and from $88^{\circ} 09^{\prime} \mathrm{E}$ to $88^{\circ} 33^{\prime}$ ' E longitudes. 


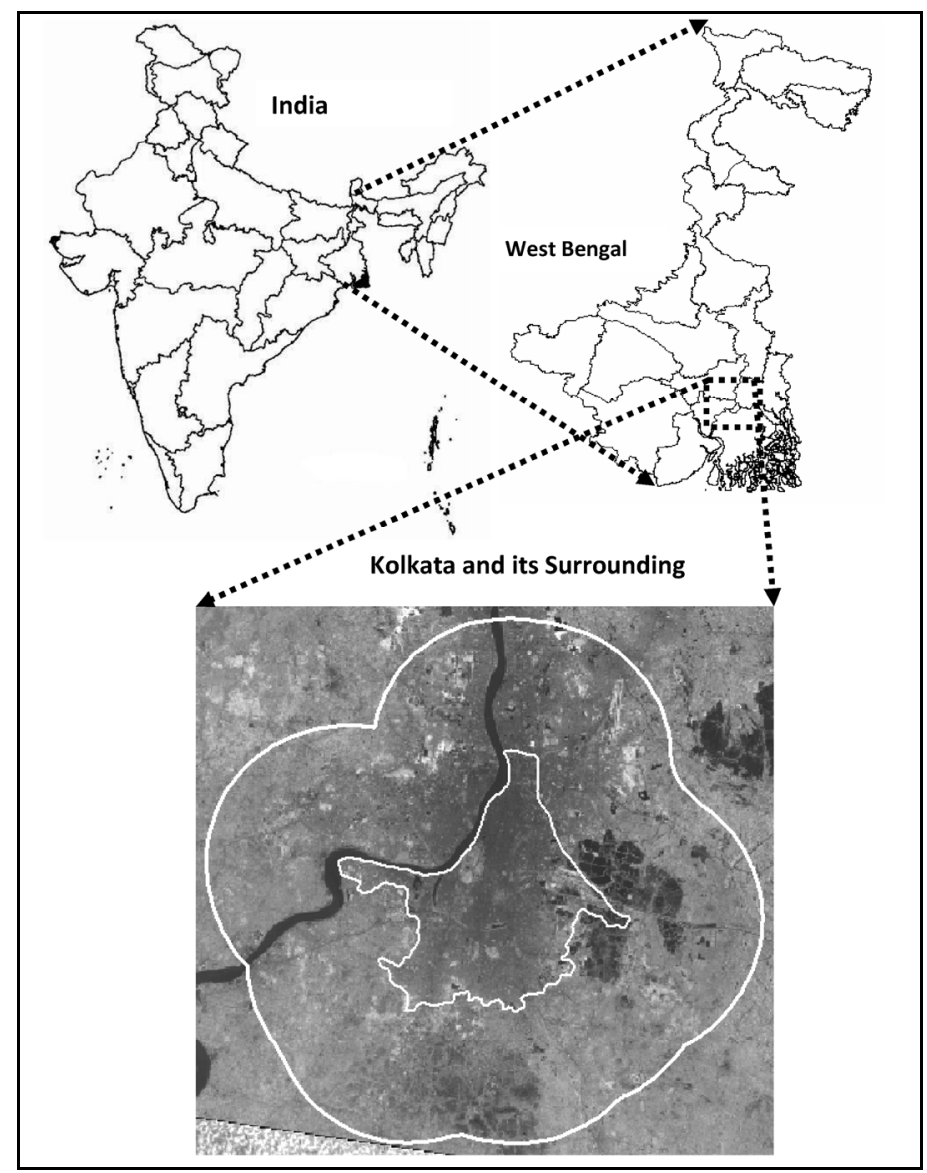

Figure 1. Location map of the study area

\section{Materials and Methods}

Satellite imageries have been used to find out the change in vegetation density in Kolkata and its sorroundings. Multi-temporal imageries from the Landsat series (Table 1) have been used.

Table 1. Specifications of the satellite images used in the study

\begin{tabular}{ccccc}
\hline Serial Number & Type of Sensor & Path/Row & Date of Acquisition & Spectral Resolution \\
\hline 1 & MSS & $149 / 45$ & 17.01 .1973 & $60 \mathrm{~m}$ \\
2 & TM & $138 / 44$ & 14.11 .1990 & $30 \mathrm{~m}$ \\
3 & & & 17.11 .2000 & $30 \mathrm{~m}$ \\
\hline
\end{tabular}

The methodology adopted in this study has been given in a sequential manner in Figure 2. 


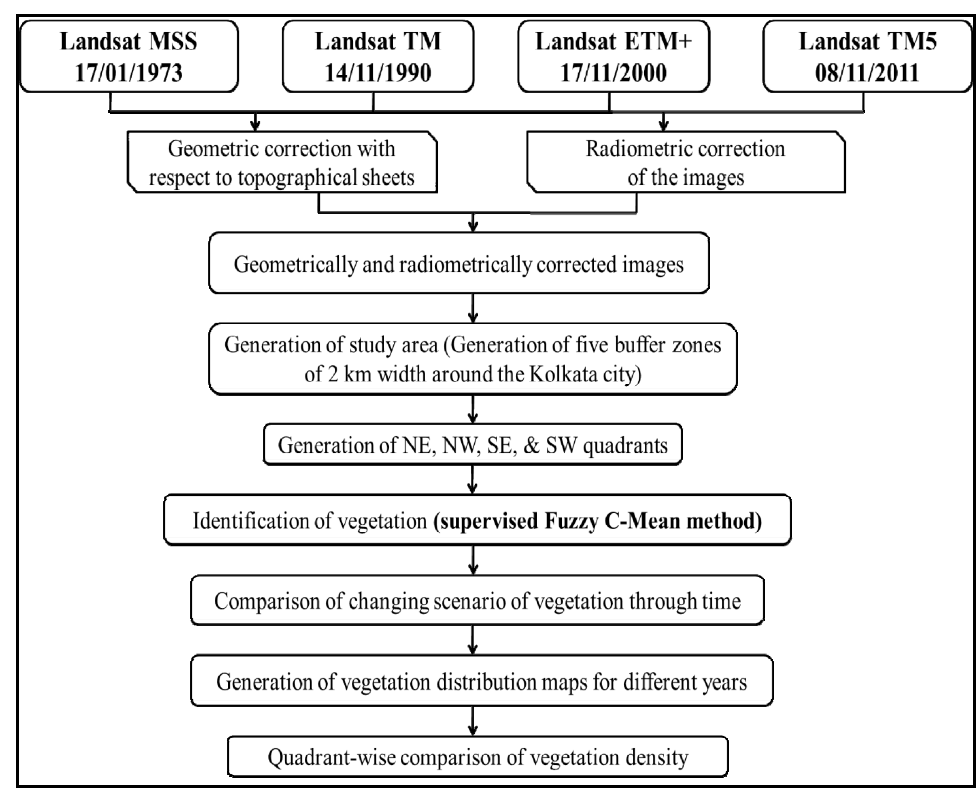

Figure 2. Flow chart showing methodology adopted

\subsection{Generation of Quadrants}

Four quadrants around the administrative boundary of Kolkata have been created based on the four cardinal directions. Each quadrant has six sectors, i.e. the quadrant itself and five more buffer zones, each of which has a width of $2 \mathrm{~km}$. For example, in the northeast (NE) quadrant, sector I is the NE quadrant itself and sectors II, III, IV, V and VI are the buffer zones around this quadrant, having a width of $2 \mathrm{~km}, 4 \mathrm{~km}, 6 \mathrm{~km}, 8 \mathrm{~km}$ and $10 \mathrm{~km}$ respectively. The sectors for each of the remaining quadrants- northwest (NW), southwest (SW) and southeast (SE) were generated. In total, 24 sectors (4 quadrants 6 sectors) have been generated in this study (Figure 3). For each of these sectors, all the vegetation cover was identified.

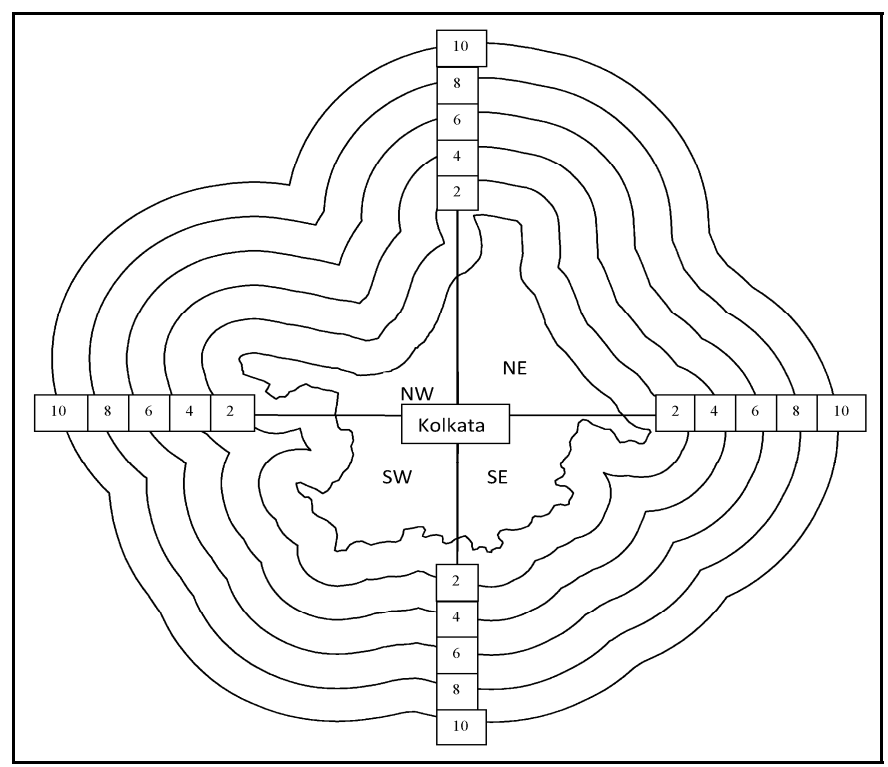

Figure 3. Quadrant-wise divisions of study area (twenty-four sectors)

\subsection{Image Rectification and Georeferencing}

The multi-temporal satellite imageries have been geometrically corrected using co-registration method, then they have been radiometrically corrected and have been converted to aparent reflectance. Radiometric calibration 
procedure facilitates the comparability of multi-temporal satellite imageries (Jensen, 2007). The 2011 image has been geometrically registered to the topographic map and then the 1973 image was geometrically registered to the 2011 base image. The root mean square error of registration was maintained at 1 pixel $(<30 \mathrm{~m})$ only.

After the geometric correction, the radiometric calibration has been performed and the corrected images were obtained. Digital Number (DN) values were converted in to spectral radiance $\left(\mathrm{L}_{\lambda}\right)$, by using the calibration coefficient given in the data header file(Chander, Markham, \& Barsi, 2007):

$$
L_{T O A}=\left(\frac{L \max _{\lambda}-L \min _{\lambda}}{Q C A L \max -Q C A L \min }\right) *(D N-Q C A L \min )+L \min _{\lambda}
$$

where, $\mathrm{Q}_{\text {cal max }}=255, \mathrm{Q}_{\text {cal min }}=0, \mathrm{Q}_{\text {cal }}=$ quantized calibrated $\mathrm{DN}$ and $\mathrm{L}_{\min \lambda}=$ spectral radiance scaled to $\mathrm{Q}_{\text {cal min }}$ $\left(\mathrm{W} / \mathrm{m}^{2} / \mathrm{sr} / \mu \mathrm{m}\right)$.

Further, spectral radiance value has been converted into reflectance by using Equation 2 (Schowengerdt, 2007)

$$
\rho=\frac{L_{T O A} \pi d^{2}}{E S U N_{\lambda} \cos \theta_{z}}
$$

where, $\rho=$ reflectance, $\mathrm{L}_{\mathrm{TOA}}=$ radiance at the top of the atmosphere, $=$ Band-dependant exo-atmospheric irradiance $\left(\mathrm{W} / \mathrm{m}^{2} / \mu \mathrm{m}\right), \theta_{\mathrm{z}}=$ solar zenith angle (degrees) and, $\mathrm{d}^{2}=$ earth-sun distance (Astronomical Units), where $\mathrm{d}$ is given by the formula:

$$
d=1.001672 * \sin \left(\frac{2 \pi(J-93.5)}{356}\right)
$$

where, $\mathrm{J}=$ Julian day.

\subsection{Image Classification}

Fuzzy classification technique has been adopted to classify the imageries. This classification technique represents a computer model in which each pixel may have partial membership of several land cover (vegetation) classes. It provides membership value for each sample in each of the classes ranging from 0 to 1 . For the present work, the Fuzzy C-Mean (FCM) algorithm (Dunn, 1973; Bezdek, 1981) has been used for the clustering process. This algorithm is built, based on iterative minimization of the objective function and is given as:

$$
J_{m}(U, v)=\sum_{i=1}^{C} \sum_{k=1}^{N} u_{i k}^{m}\left\|y_{k}-v_{i}\right\|_{A}^{2}
$$

where, $\mathrm{Y}=\{\mathrm{Y} \sim, \mathrm{Y} 2 \ldots \mathrm{YN}\} \subset \mathrm{R}^{\mathrm{n}}=$ the data,

$\mathrm{c}=$ number of clusters in $\mathrm{Y} ; \quad 2 \leq \mathrm{c} \leq \mathrm{n}$,

$\mathrm{m}=$ weighting exponent; $\quad 1 \leq \mathrm{m}<\infty$,

$\mathrm{U}=$ fuzzy c-partition of $\mathrm{Y} ; \quad \mathrm{U} \in \mathrm{M}_{\mathrm{fc}} \mathrm{V}=\left(\mathrm{v}_{1}, \mathrm{v}_{2} \ldots \mathrm{v}_{\mathrm{c}}\right)=$ vectors of centres,

$\mathrm{v}_{\mathrm{i}}=\left(\mathrm{v}_{\mathrm{i} 1}, \mathrm{v}_{\mathrm{i} 2}, . ., \mathrm{v}_{\mathrm{in}}\right)=$ center of cluster $\mathrm{i}$,

\|\|$_{A}=$ induced A-norm on $\mathrm{R}^{\prime \prime}$

$A=$ positive-definite $(n \times n)$ weight matrix.

The membership values assure the following three constraints:

$$
\begin{gathered}
\sum_{i=1}^{C} u_{i k}=1 \\
0 \leq u_{i k} \leq 1 \text { where } i \in\{1, \ldots, C\}, k \in\{1, \ldots, N\} \\
\text { Where } k \in\{1, \ldots, N\} \\
\sum_{k=1}^{N} u_{i k}>0 \text { where } i \in\{1, \ldots, C\}
\end{gathered}
$$


The objective function represents the sum of the square of the Euclidean distances amid each input sample and the corresponding cluster centre, with the distances weighted by the fuzzy memberships. This is an iterative algorithm and makes use of the following equations:

$$
\begin{gathered}
\hat{v}_{i}=\left[\sum_{k=1}^{N} u_{i k}^{m} y_{k}\right] / \sum_{k=1}^{N} u_{i k}^{m} \\
\hat{u}_{i k}=1 / \sum_{j=1}^{C}\left[\left\|y_{k}-v_{i}\right\| /\left\|y_{k}-v_{j}\right\| \|^{2 /(m-1)}\right.
\end{gathered}
$$

In Fuzzy $\mathrm{C}$ mean, it tends to divide the finite group of $\mathrm{n}$ elements into the group of fuzzy $\mathrm{C}$ clusters. On the basis of finite data, the algorithm gives centre of c clusters and the partition matrix which provide the information about the degree to which the element belongs to the cluster $\mathrm{c}$. Here, in fuzzy clustering, each point has a degree to belong to more than one cluster. Thus, those at the edge of the cluster have degree of less belonging than the points at the centre of the cluster. The degree of a point to belong to a cluster is inversely related to the distance from the point to the cluster centre. For calculating the cluster centre, all input samples were taken into account and contributions of each of these samples were weighted by the membership values. For an individual sample, its membership value in each class is dependent on its distance to the corresponding cluster centre. The weight factor, $\mathrm{m}$, diminishes the influence of small membership values. The greater is the value of $\mathrm{m}$, the lesser will the influence of samples with smaller membership values (Bezdek, Ehrlich, \& Full, 1984).

\subsection{Accuracy Assessment}

The accuracy of a classification is estimated by the error matrix. Different categories of an automated classification are compared by an error matrix, with known reference data or by ground truthing (Congalton \& Green, 2009). From the error matrix, various classification errors such as inclusions and exclusions are identified. The overall accuracy is obtained by dividing the total number of correctly classified pixels by the total number of reference pixels. However, it does not indicate how well each of the classes has been classified. It is, however, important to assess the accuracy of each of the classes and here, two useful concepts are producer's accuracy and user's accuracy. Producer's accuracy is the probability that a pixel in a given class will be classified correctly; on the other hand, user's accuracy is the probability that a pixel classified as a particular class in an image is actually that class on the ground (Story \& Congalton, 1986). Producer's accuracy is usually calculated by dividing the total number of correctly classified pixels in each class by the number of training set pixels used for that class. User's accuracy is computed by dividing the number of correctly classified pixels in each class by the total number of pixels that were classified in that class (Congalton, 1991).

In this study, the Kappa Coefficient has been used to assess the accuracy of the classification. Kappa analysis gives the KHAT statistic, which is a measure of the degree of agreement of various accuracies (Lillesand, Kiefer, \& Chipman, 2004) (Table 2).

Table 2. KHAT statistic for the accuracy assessments

\begin{tabular}{lccccccc}
\hline \multicolumn{2}{c}{ Class ReferenceClassified } & Number of & Producers & Overall & Users & Kappa \\
Name & Total & Total & Correct Points & Accuracy (\%) & Accuracy (\%) & Accuracy (\%) & Khat \\
\hline 1973 & 52 & 60 & 52 & 100 & 93.60 & 86.67 & 0.87 \\
1990 & 53 & 60 & 52 & 98.11 & 92.80 & 86.67 & 0.86 \\
2000 & 55 & 60 & 54 & 98.18 & 94.40 & 90.00 & 0.89 \\
2011 & 56 & 60 & 54 & 96.43 & 93.60 & 90.00 & 0.87 \\
\hline
\end{tabular}

The given table explains the accuracy of the classification where overall accuracy and Kappa for 1973 are $93.60 \%$ and 0.87 , for 1990 they are $92.80 \%$ and $0.86,2000$ represents $94.40 \%$ and 0.89 and for 2011 they are $93.60 \%$ and 0.87 respectively. It is given by:

$$
k=\frac{N \sum_{i=1}^{r} X_{i i}-\sum_{i=1}^{r}\left(X_{i+1} \times X_{+i}\right)}{N^{2}-\sum_{i=1}^{r}\left(X_{i=1} \times X_{+i}\right)}
$$


where, $\mathrm{k}=$ KHAT statistic.

\section{Results and Discussion}

\subsection{Spatial Variation of Vegetation Zones}

The quadrant-wise distribution of vegetation during the years under study has been shown in Figure 4. In 1973, the highest vegetation cover was in the western part of the study area. In both the NW and SW quadrants, maximum concentration was within the $8 \mathrm{~km}$ and $10 \mathrm{~km}$ buffer zones. In the eastern part of the study area, the distribution of vegetation was scattered. In the SE quadrant, vegetation seemed to have concentrated in an angular pattern. The scarce concentration of vegetation in the NE quadrant during this period may be partially attributed to the development of Salt Lake, a satellite township on the eastern fringes of Kolkata, which was built during this period on land reclaimed from marshes. In sector I, i.e. Kolkata city itself, some trees were cut down during this period to aid the development of the Metro Railway system.

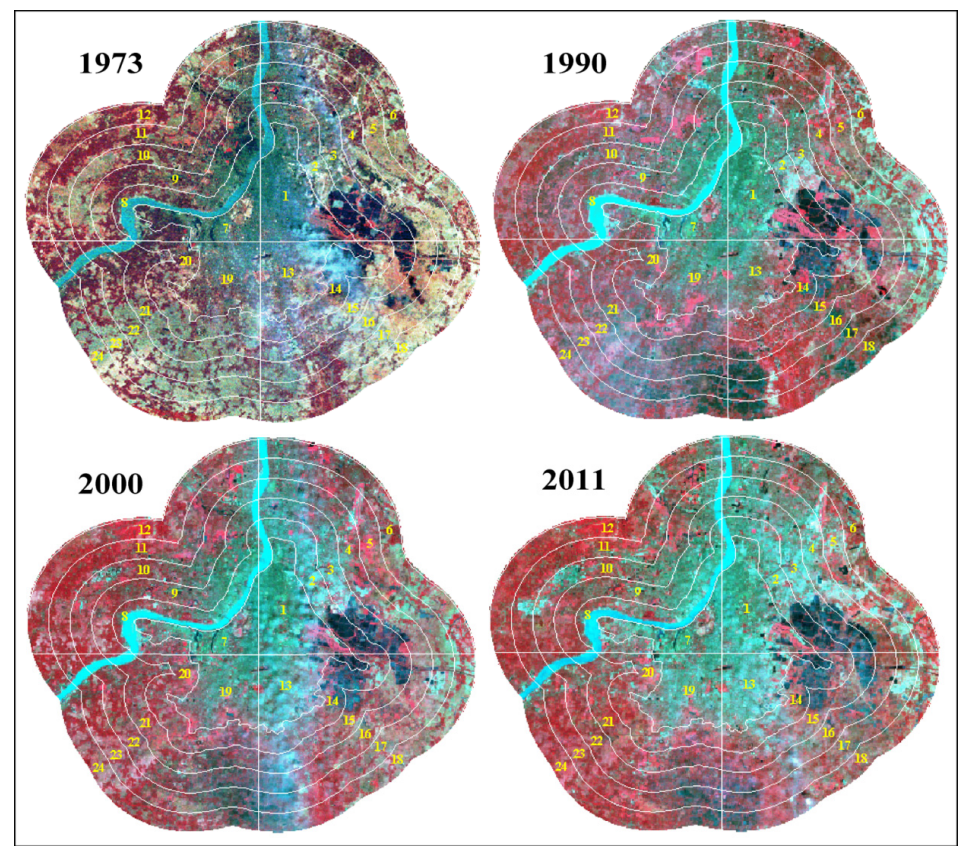

Figure 4. Quadrant-wise multi-temporal satellite images

The scenario was quite similar in 1990 but in 2000, there is a significant change of vegetation concentration. Vegetation was cut down in large numbers to accommodate the increased population of KMA due to the inclusion of several areas, particularly in the western and southeastern parts like Joka, Diamond Harbour, Baruipur and Narendrapur within its ambit. Many open grounds and parks were converted into residential and commercial blocks as India liberalized her economy in 1991. A large part of the East Kolkata Wetlands, a man-made wetland on the eastern fringes of the city, was converted into agricultural lands and pisciculture ponds (Banerjee, 2009). Also large plots of hitherto unused, vegetated lands along the Eastern Metropolitan Bypass were occupied by commercial, academic and medical organizations and were converted into shopping malls, schools, colleges and hospitals respectively. Consequently, vegetation cover declined rapidly between 1990 and 2000. By 2011, the concentration of vegetation had declined consistently throughout the region. Only the westernmost periphery, around Diamond Harbour, has been able to retain some considerable amount of vegetation. This is not surprising because massive economic development has taken place throughout the region since 2000. Many multi-national companies, residential complexes and community service centres like swimming pools, cricket coaching centres etc. have developed throughout the study area post 2000.

\subsection{Temporal Variation of Vegetation Cover}

The changed scenarios of vegetation with respect to the different quadrants have been shown in Figure 5. In the NE quadrant, the area under vegetation cover has increased from 1973 to 2011 in all the sectors except the sixth sector (i.e. $10 \mathrm{~km}$ buffer area), where the vegetation cover is uniformly low. 


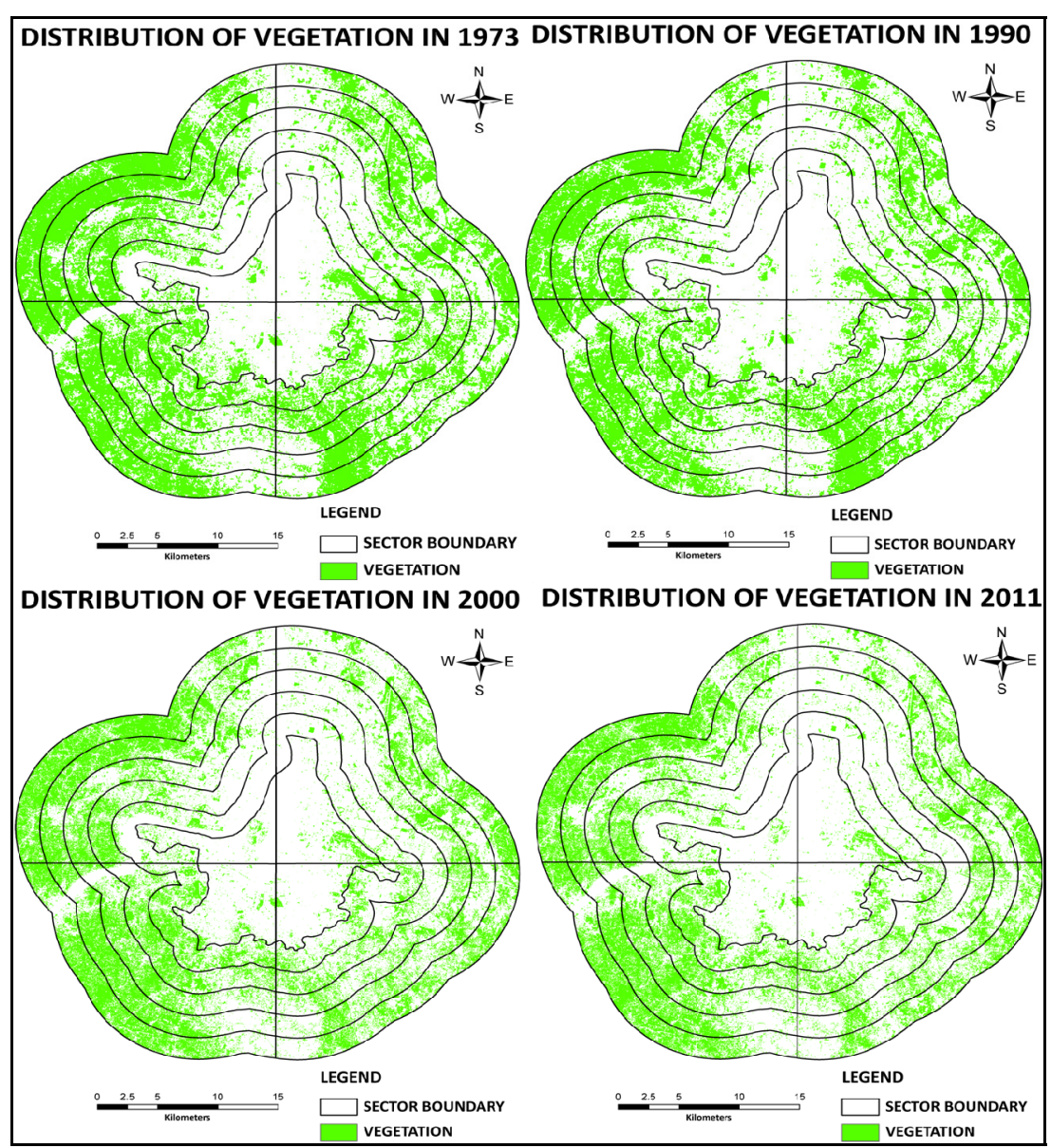

Figure 5. Sector-wise distribution of vegetation in the study area during 1973 to 2011

In the SE quadrant, the vegetation cover is quite healthy throughout 38 years. It is particularly noteworthy that in this quadrant, sector I (proper city) has considerable vegetation cover throughout. However, the $8 \mathrm{~km}$ buffer area had consistently low vegetation cover.

The SW quadrant is characterized by the highest concentration of vegetation in the $6 \mathrm{~km}$ and $8 \mathrm{~km}$ buffer zones, whereas the $2 \mathrm{~km}, 4 \mathrm{~km}$ and $10 \mathrm{~km}$ zones have more or less equal areas under vegetation, ranging from 20 to 25 sq. km. during all the years. However, the vegetation cover is significantly low within the proper city.

In the NW quadrant, the scenario is similar to the NE quadrant. The vegetation cover within the city area has been insignificant throughout.

\subsection{Spatio-temporal Variation Of Vegetation Density}

Table 3 shows the sector-wise distribution of vegetation density in Kolkata and its environs during the study period. It is evident from the table that density of vegetation has been declining across all the sectors at an almost uniform rate throughout the study area (Figure 6). Within the NE quadrant, maximum density is found in the 4 $\mathrm{km}, 6 \mathrm{~km}$ and $8 \mathrm{~km}$ buffer zones, although the density is constantly decreasing with the passage of time. 
Table 3. Sector-wise distribution of vegetation density in different years

\begin{tabular}{|c|c|c|c|c|c|}
\hline $\begin{array}{l}\text { Sector } \\
\text { ID }\end{array}$ & Quadrant & $\begin{array}{l}\text { Density } \\
\text { (1973) }\end{array}$ & $\begin{array}{c}\text { Density } \\
(1990)\end{array}$ & $\begin{array}{l}\text { Density } \\
(2000)\end{array}$ & Density (2010) \\
\hline 1 & $\mathrm{NE}$ & 0.1117 & 0.1063 & 0.0822 & 0.0751 \\
\hline 2 & $\mathrm{NE}$ & 0.1880 & 0.1479 & 0.0759 & 0.0576 \\
\hline 3 & $\mathrm{NE}$ & 0.3286 & 0.2969 & 0.2210 & 0.1809 \\
\hline 4 & $\mathrm{NE}$ & 0.4289 & 0.3903 & 0.3210 & 0.2769 \\
\hline 5 & $\mathrm{NE}$ & 0.4659 & 0.4305 & 0.3642 & 0.3345 \\
\hline 6 & $\mathrm{NE}$ & 0.1462 & 0.1184 & 0.0765 & 0.0677 \\
\hline 7 & NW & 0.0682 & 0.0611 & 0.0652 & 0.0590 \\
\hline 8 & NW & 0.3756 & 0.2691 & 0.2660 & 0.2352 \\
\hline 9 & NW & 0.4651 & 0.3624 & 0.3452 & 0.2926 \\
\hline 10 & NW & 0.7259 & 0.6331 & 0.5676 & 0.5169 \\
\hline 11 & NW & 0.7447 & 0.6714 & 0.6380 & 0.6085 \\
\hline 12 & NW & 0.1686 & 0.1200 & 0.1235 & 0.1078 \\
\hline 13 & SE & 0.4720 & 0.4174 & 0.2800 & 0.2544 \\
\hline 14 & SE & 0.5029 & 0.4572 & 0.3151 & 0.2793 \\
\hline 15 & SE & 0.4409 & 0.4113 & 0.3279 & 0.2964 \\
\hline 16 & SE & 0.4306 & 0.4114 & 0.2499 & 0.2322 \\
\hline 17 & SE & 0.1099 & 0.1031 & 0.0647 & 0.0622 \\
\hline 18 & SE & 0.5001 & 0.4817 & 0.4128 & 0.3769 \\
\hline 19 & SW & 0.1692 & 0.1023 & 0.0918 & 0.0791 \\
\hline 20 & SW & 0.5106 & 0.4368 & 0.4743 & 0.4473 \\
\hline 21 & SW & 0.4900 & 0.4195 & 0.4543 & 0.4311 \\
\hline 22 & SW & 0.6004 & 0.5559 & 0.5562 & 0.5341 \\
\hline 23 & SW & 0.6531 & 0.5896 & 0.5746 & 0.5496 \\
\hline 24 & SW & 0.5310 & 0.4563 & 0.4574 & 0.4209 \\
\hline
\end{tabular}

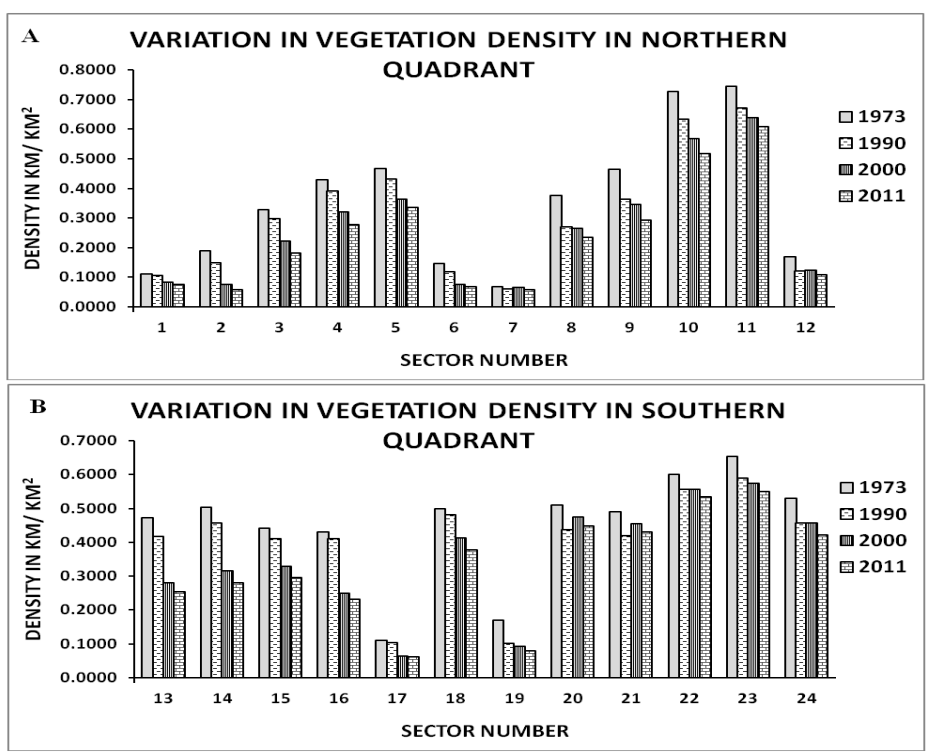

Figure 6. Year-wise difference in vegetation density in northern and southern quadrant 


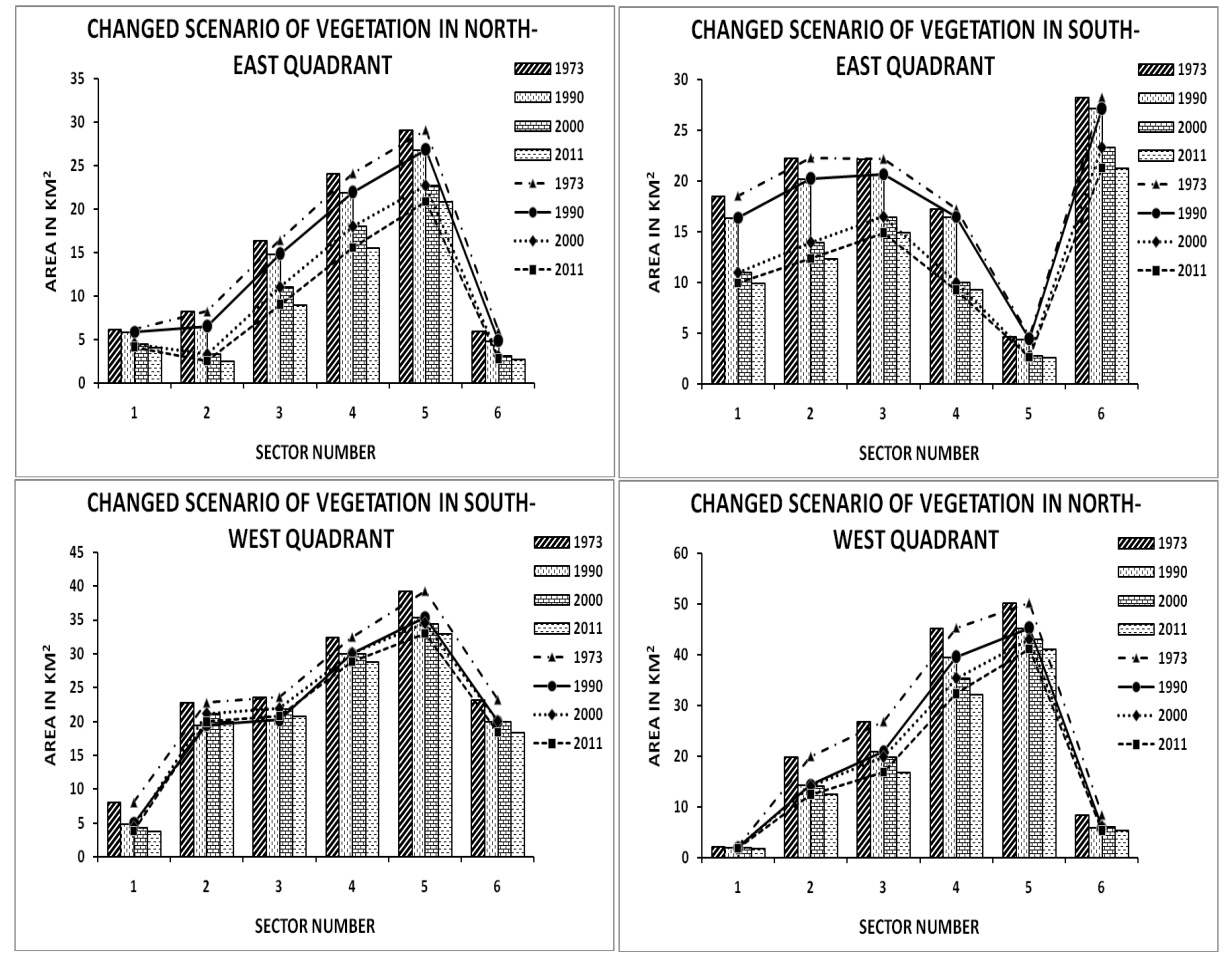

Figure 7. Sector-wise changed scenario of vegetation in different quadrants

In the SE quadrant, the density of vegetation has been same in both 1973 and 1990, but since then, the density has been declining. The least density in this quadrant is found in the $8 \mathrm{~km}$ buffer zone.

The SW quadrant, with the exception of the proper city, has considerable vegetation density through both space and time, but maximum density has been found within the $8 \mathrm{~km}$ buffer zone.

In the NW quadrant, the highest vegetation density has been found within the $6 \mathrm{~km}$ and $8 \mathrm{~km}$ buffer areas and the least density is found in the proper city and the $10 \mathrm{~km}$ buffer area, where there are many small and medium-scale industries.

In general, the western quadrants appear to be more densely vegetated than the eastern quadrants and this is likely to have positive effect on its ecology. Also, the average vegetation density in the southern quadrants $(0.38$ $\mathrm{km} / \mathrm{sq} . \mathrm{km}$.) is much higher than that in the northern quadrants $(0.29 \mathrm{~km} / \mathrm{sq} . \mathrm{km}$.) (Figure 7).

\section{Conclusions}

The vegetation cover of Kolkata and its surroundings has been analyzed using satellite imageries for a period of 38 years. It has been seen that the vegetation cover has constantly declined and the rate of declination has bin accelerating since 2000. The present vegetation appears to be concentrated in buffer areas of $4 \mathrm{~km}, 6 \mathrm{~km}$ and 8 $\mathrm{km}$. The continual decline is due to the rapid economic development that is going on at present. Many unplanned constructions are being made at the cost of the city's greenery. This is adversely affecting the ecological balance of the study area. The implications of such imbalance could prove to be fatal in the near future. Although some restoration measures have started to be adopted in the recent years, such efforts are far and few and often cannot keep pace with the rate of destruction of vegetation. It is important that mass-awareness programs are carried out to make the local people aware of the benefits of having greenery. Moreover, strict laws, regarding carrying out construction activities, should be made. Care should be taken to ensure that such laws are strictly adhered to at all costs.

\section{Acknowledgements}

The authors wish to thank the Global Land Cover Facility (GLCF) and USGS Global Visualization Viewer for providing quality satellite imageries without which the study would not have been possible.

\section{References}

Altobello, A., Bressan, E., Feoli, E., Gannis, P., \& Martini, F. (2007). Improving knowledge of urban vegetation 
by applying GIS technology to existing databases.Applied Vegetation Science, 10, 203-210. http://dx.doi.org/10.1111/j.1654-109X.2007.tb00518.x

Arnot, C., \& Fisher, P. (2007). Mapping the ecotone with fuzzy sets. In A. Morris, and. Kokhan (Eds.). Geographic uncertainty in environmental security (19-32). Heidelberg: Springer.

Banerjee, M. (2009). Environmental changes in East Kolkata Wetlands: 1990-2000. Unpublished M.Phil.dissertation, Jawaharlal Nehru University, New Delhi.

Bezdek, J. C. (1981). Pattern recognition with fuzzy objective function algorithms. New York: Plenum Press. http://dx.doi.org/10.1007/978-1-4757-0450-1

Bezdek, J. C., Ehrlich, R., \& Full, W. (1984). FCM: The Fuzzy C-Means Clustering Algorithm. Computers \& Geosciences, 10, 191-203. http://dx.doi.org/10.1016/0098-3004(84)90020-7

Blaschke, T., \& Strobl, J. (2001). What's wrong with pixels? Some recent developments interfacing remote sensing and GIS. ZeitschriftfürGeoinformationssysteme, 14, 12-17.

Bremner, J., Frost, A., Haub, C., Mather, M., Ringheim, K., \& Zuehlke, E. (2010). World population highlights: key findings from the PRB's 2010 World Population Data Sheet.Population Bulletin, 65, 1-12. Retrieved on April 18, 2012, from http://www.prb.org/Publications/PopulationBulletins/2010/worldpopulationhighlights2010.aspx

Brinkmann, K., Schumacher, J., Dittrich, A., Kadaore, I., \& Buerkert, A. (2012). Analysis of landscape transformation processes in and around four West African cities over the last 50 years. Landscape and Urban Planning, 105, 94-105. http://dx.doi.org/10.1016/j.landurbplan.2011.12.003

Census of India. (2011a). Area, population, decennial growth rate and density for 2001 and 2011 at a glance for West Bengal and the districts. Provisional population totals paper 1 for 2011: West Bengal. Retrieved April 18, 2012, from http://www.censusindia.gov.in/2011-prov-results/prov_data_products_wb.html

Census of India. (2011b). Urban agglomerations/cities having population 1 million or above.Provisional population totals paper 2 for 2011: India. Retrieved April 18, 2012, from http://www.censusindia.gov.in/2011-prov-results/paper2-vol2/prov_results_paper2_indiavol2.html

Chander, G., Markham, B. L., \& Barsi, J. A. (2007). Revised Landsat-5 Thematic Mapper radiometric calibration. IEEE Geoscience and Remote Sensing Letters, 4, 490-494. http://dx.doi.org/10.1109/TGRS.2003.8184644

Congalton, R. G. (1991). A review of assessing the accuracy of classifications of remotely sensed data. RemoteSensing of Environment, 37, 35-46. http://dx.doi.org/10.1016/0034-4257(91)90048-B

Congalton, R. G., \& Green, K. (2009). Assessing the accuracy of remotely sensed data: principles and practices (2nd ed.). Boca Raton: CRC Press.

Dunn, J. C. (1973). A fuzzy relative of the ISODATA process and its use in detecting compact, well-separated clusters.Journal of Cybernetics, 3, 32-57. http://dx.doi.org/10.1080/01969727308546046

Emmanuel, R. (1997). Urban vegetational change as an indicator of demographic trends in cities: the case of Detroit. Environment and Planning B, 24, 415-426. http://dx.doi.org/10.1068/b240415

Foody, G. M. (1992). A fuzzy sets approach to the representation of vegetation continua from remotely sensed data -An example from lowland heath. Photogrammetric Engineering and Remote Sensing, 58, 221-225.

Fuller, R. A., Irvine, K. N., Devine-Wright, P., Warren, P. H., \& Gaston, K. J. (2007). Psychological benefits of greenspace increase with biodiversity. Biology Letters, 3, 390-394. http://dx.doi.org/10.1098/rsbl.2007.0149

Government of India. (2006). Towards faster and more inclusive growth: an approach to the $11^{\text {th }}$ Five Year Plan. New Delhi: Planning Commission of India.

Grimm, N. B., Faeth, S. H., Golubiewski, N. E., Redman, C. L., Wu, J., Bai, X., \& Briggs, J. M. (2008). Global change and the ecology of cities. Science, 319, 756-760. http://dx.doi.org/10.1126/science.1150195

Kolkata Metropolitan Development Authority. (2010). Introducing KMA. Kolkata: Kolkata Metropolitan Development Authority.

Korwik, I. (1990). Some responses of flora and vegetation to urbanization in central Europe. In H. Sukopp, S. Hejny, and I. Kowarik (Eds.) Urban ecology: plants and plant communities in urban environments (pp. 45-74). The Hague: SPB Academic Publishing.

Kuo, F. E., \& Sullivan, W. C. (2001). Environment and crime in the inner city: does vegetation reduce crime? 
Environment and Behaviour, 33, 343-367. http://dx.doi.org/10.1177/0013916501333002

Kwarteng, A. Y., \& Chavez Jr., P. S. (1998). Change detection study of Kuwait City and environs using multi-temporal Landsat Thematic Mapper data. International Journal of Remote Sensing, 19, 1651-1662. http://dx.doi.org/10.1080/014311698215162

Lillesand, T. M., Kiefer, R. W., \& Chipman, J. W. (2004). Remote sensing and image interpretation (5th ed.). John Wiley \& Sons, Singapore.

Liu, L., Wang, J., \& Zhao, C. (2009). Analysis of the changes of vegetation coverage of western Beijing mountainous areas using remote sensing and GIS. Environmental Monitoring and Assessment, 153, 339-349. http://dx.doi.org/10.1007/s10661-008-0360-0

Lucieer, A. (2006). Fuzzy classification of sub-Antarctic vegetation on Heard Island based on high-resolution satellite imagery. IEEE Geoscience and Remote SensingSymposium, 2006, July 23-August 4, 2777-2780.

Lu, D., \& Weng, Q. (2007). A survey of image classification methods and techniques for improving classification $\begin{array}{lllll}\text { performance.International Journal of Remote } & \text { Sensing, 28, }\end{array}$ http://dx.doi.org/10.1080/01431160600746456

Mundia, C. N., \& Aniya, M. (2006). Dynamics of landuse/cover changes and degradation of Nairobi city, Kenya.Land Degradation and Development, 17, 97-108. http://dx.doi.org/10.1002/ldr.702

Nagendra, H., Nagendran, S., Pal. S., \& Pareeth, S. (2012). Graying, greening and fragmentation in the rapidly expanding Indian city of Bangalore.Landscape and Urban Planning, 105, 400-406. http://dx.doi.org/10.1016/j.landurbplan.2012.01.014

Oldeland, J., Dorigo, W., Lieckfeld, L., Lucieer, A., \& Jürgens, N. (2010). Combining vegetation indices, constrained ordination and fuzzy classification for mapping semi-natural vegetation units from $\begin{array}{lllll}\text { hyperspectralimagery.RemoteSensing of } & \text { Environment, } & 114, & 1155-1166 .\end{array}$ http://dx.doi.org/10.1016/j.rse.2010.01.003

Oke, T. R. (1973). City size and the urban heat island.Atmospheric Environment, 7, 769-779. http://dx.doi.org/10.1016/0004-6981(73)90140-6

Stern, N. (2007). The economics of climate change: the Stern Review. Cambridge: Cambridge University Press.

Story, M., \& Congalton, R. (1986). Accuracy assessment: a user's perspective. Photogrammetric Engineering and Remote Sensing, 52, 397-399.

Von Stülpnagel, A., Horbert, M., \& Sukopp, H. (1990). The importance of vegetation for the urban climate. In H. Sukopp, S. Hejny and I. Kowarik (Eds.) Urban ecology: plants and plant communities in urban environments (pp. 175-193). The Hague: SPB Academic Publishing.

Williams, N. S .G., Schwartz, M. W., Vesk, P. A., McCarthy, M. A., Hahs, A. K., Clemants, S. E., ... McDonnell, M. A. (2009). A conceptual framework for predicting the effects of urban environments on floras. Journal of Ecology, 97, 4-9. http://dx.doi.org/10.1111/j.1365-2745.2008.01460.x

Zhang, J., \& Foody, G. M. (2001). Fully-fuzzy supervised classification of sub-urban land cover from remotely sensed imagery: Statistical and artificial neural network approaches. International Journal of Remote Sensing, 22, 615-628. http://dx.doi.org/10.1080/01431160050505883 